and generosity, and all areas of human endeavour can at times be characterized in these terms, but not often.

Why are people so loath to apply to themselves the basic principles that they apply to everyone else? Because it all depends on whose ox is being gored. Throughout this book, Gould preaches peace. In particular, he would like to end his conflict with Wilson, but in the final third of this book, Gould cannot resist taking one last swipe at his longtime adversary. Although Gould is as gentle and gentlemanly as possible, he attacks Wilson's reductionism under the guise of William Whewell's 'consilience of inductions'. A consilience of inductions occurs when the data used to support one hypothesis also turn out to support another hypothesis as well. Gould argues that Wilson has got Whewell all wrong: Whewell's notion of consilience is not in the least reductionistic.

In his final collection of essays, I Have Landed, Gould could not help wondering what comes next. Unfortunately, what came next was a second bout of cancer and premature death. But had he beaten the odds a second time, I think Gould would have continued to do battle with Wilson. I picture two warriors sinking into quicksand as they flail away at each other one more time just one more time.

David L. Hull is emeritus professor in the

Department of Philosophy, Northwestern

University, 1818 Hinman Avenue, Evanston, Illinois 60208-1315, USA.

\section{Einstein's view of Germany}

\section{Einstein in Berlin}

by Thomas Levenson

Bantam Doubleday Dell: 2003. 400 pp.

$\$ 25.95$

\section{Freeman J. Dyson}

Thomas Levenson is a film-maker who produces documentary films for public television. He has a sharp eye for the dramatic events and personal details that bring history to life. His latest book is a social history of Germany from 1914 to 1933, when Albert Einstein lived in Berlin. The picture of the city's troubles comes into clearer focus when viewed through Einstein's eyes. He was a good witness, observing the life of the city in which he played an active role but from which he remained emotionally detached.

Einstein wrote frequent letters to his old friends in Switzerland and his new friends in Germany, recording events as they happened and describing his hopes and fears. His daily life and activities come intermittently into the narrative, but are not the main theme. The main theme is the tragedy of the First World War, a tragedy that began in 1914 but

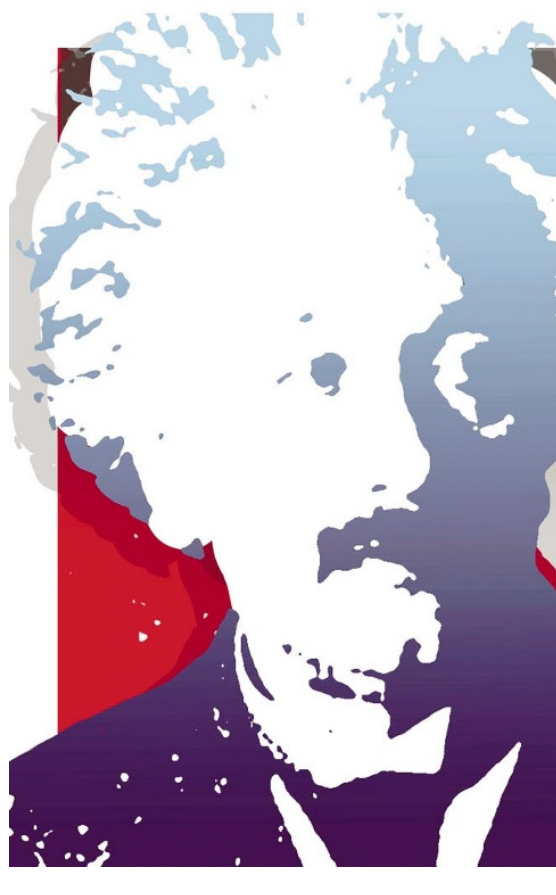

did not end with the war in 1918. It continued to torment the citizens of Berlin until 1933 , and led them finally to put their fate in the hands of Hitler. Hitler was able to gain power by promising to erase the tragedy and bring back the happy days of the empire when Germany was prosperous and united.

"There are, to be sure, too many biographies of Einstein and not enough of Poincaré," writes Peter Galison in a forthcoming book, Einstein's Clocks and Poincaré's Maps. Every aspect of Einstein's life - the personal, the political, the scientific and the philosophical - has been described in detail and analysed in depth by his various biographers. The world does not need another Einstein biography. Fortunately, Einstein in Berlin is not a biography. Levenson has borrowed everything he needs from the published correspondence and the existing biographies of Einstein, with full acknowledgements and an excellent bibliography. The new and original aspect of this book is the context in which Einstein is placed: an in-depth study of the social pathology that gripped Berlin from the day that Einstein arrived in 1914 to the day he left in 1932.

The tragedy is a play in two acts: the first act covers the years of war, and the second act the years of the Weimar Republic. The most remarkable feature of the first act is the general belief among Einstein's friends in Berlin that the war was winnable. The war was widely welcomed as an opportunity for Germany to achieve its proper status as a great power. Einstein observed that his academic friends and colleagues were even more deluded with patriotic dreams of grandeur than the ordinary citizens that he met in the street.

For example, in June 1918, after the last great German offensive on the Western front had failed, Felix Klein, a mathematician second only to David Hilbert in fame and authority, spoke in Göttingen to an audience of leading industrialists and government officials. He talked confidently of the coming victorious conclusion of the war, of the harmonious collaboration of German science with industry and the armed forces, and of the expected increase in support for mathematical education and research after the victory was won.

The state of mind of the mandarins in Berlin was very different from that of their enemies in Paris and London. In Paris the war was seen as a desperate struggle for survival. The guns on the Western front were so close that everyone in Paris could hear them. In Britain the war was seen as a tragedy that had done irreparable harm to Britain and to European civilization, no matter who won it. When the war came to an end in November 1918, the British public looked back on it as an unspeakable horror that should never under any circumstances be allowed to happen again. But a large part of the German public looked back on it differently, as a test of strength that they could have won if they had not been stabbed in the back by traitors at home. This book explains how that fatal German sense of betrayal came into being.

The second act of the tragedy is the story of the slow collapse of the Weimar Republic and the rapid rise of Hitler. Einstein was a firm supporter of the republic, but he saw which way the wind was blowing. One episode in the tragedy epitomizes the whole story. Erich Remarque's book Im Westen Nichts Neues was published in 1929 and immediately became an international bestseller. It is the finest fictional account of the First World War, as seen through the eyes of a group of young Germans who die pointlessly 
in the carnage of the Western front. In 1930 it was made into a Hollywood film, All Quiet on the Western Front, which was shown all over the world - except in Germany. When the film's distributors tried to show it in Berlin, Hitler's friend Joseph Goebbels organized a riot in the cinema. Further Nazi demonstrations and violent protests against the film followed. The Weimar government then banned the film throughout Germany because the Nazis considered it unpatriotic.

This episode explains a mystery in my own family. One of my relatives, who is now 94 years old, has lived in Germany all her life and grew up in the Weimar years. Many years ago I gave her Remarque's book to read and she found it very moving. "This book is wonderful," she said. "Why didn't they let us read it when it was published? That was before the Hitler time, but we were told it was disgusting and shameful, and that respectable people should not read it." So the respectable Germans of her generation, even those who were not Nazis, did not read Remarque. I had always wondered why, and now I know.

Freeman J. Dyson is at the Institute for Advanced Study, Princeton, New Jersey 08540, USA.

\section{...…ㄱ...... Getting heated over glaciation}

\section{Snowball Earth \\ by Gabrielle Walker \\ Crown Publishers: 2003. 256 pp. \$24.95 \\ Bloomsbury: 2003. 16.99}

\section{Euan Nisbet}

Snowballs can be fun. But when they have rocks in them, the arguments start, just as between Calvin and Susie in the comic strip Calvin and Hobbes. Snowball Earth is a Hobbes-eye view of the succession of missiles, ambushes and strategies in the longrunning skirmishes over the idea that the Earth may have become so cold 600 million years ago that even the tropics froze over. The scene is superbly described, and each throw is meticulously followed from the gathering of the snow to the splat on the target. But a warning: it gets personal and gossipy - snowballologists will need many measures of generous spirit to read this.

The snowball debate first rumbled around the darker recesses of the Spitsbergen room of Cambridge University's Sedgwick Museum 30-40 years ago. Brian Harland had suggested that there had been a great glaciation just before the start of the Cambrian period. Few believed him beyond the confines of the Sedgwick Museum, and even within I recall scepticism (including my own). The new ideas of plate tectonics could surely explain most things, even glacial sediments closely juxtaposed to tropical deposits. We knew that rapid continental motion occurred: India's march northwards showed that. Nevertheless, Harland serenely held to his views, supported later by Mike Hambrey. Then Joe Kirschvink published the briefest of notes on 'Snowball Earth', lost in a fine book, The Proterozoic Biosphere, which was widely read but so vast that its most common use is as a doorstop. There languished the notion.

The Canadian government intervened, deciding in its wisdom to deconstruct what was then arguably the finest (and economically most useful) national geological survey on Earth. Paul Hoffman, a distinguished Arctic field geologist, was unable to work as usual. He departed south and turned his attention to Namibian rocks laid down in the latest Proterozoic, the time just before the Cambrian. What he found were rocks deposited in glacial conditions. But puzzlingly, these rocks were closely juxtaposed with carbonate sediments laid down in warm conditions. Moreover, the succession was very similar to the Spitsbergen rocks that Harland's group had studied.

The 'snowball' idea states that around 600 million years ago there were episodes when even in the tropics the ocean surface froze. The white, icy planet then reflected so much sunlight that the condition persisted. Life luckily survived, presumably in Noah's Arks of habitat in warm water around hot springs or photosynthesizing in open channels in the icy ocean. Eventually, as carbon dioxide continued to degas from volcanoes, the atmospheric greenhouse became so strong that tropical melting began. As ice melted, the newly darkening planet would have absorbed heat, a positive feedback leading to runaway warming. This would have been exacerbated by the release of dissolved carbon dioxide from the heating oceans and methane from vast hydrate stores, so the snowball suddenly flipped to a hothouse hell.

Gabrielle Walker recounts in racy detail the chain of discovery. Hidden in the social froth, she provides nuggets of gold: simple explanations of complex evidence. Carbon isotopes, facies analysis, methane hydrates, metazoan evolution - complicated topics all - slip down with spoonfuls of scandal sugar. The book lucidly exposes the observations that shaped the hypothesis and its testing, the critics and the bases of their criticisms, and the subsequent growth of the idea as the debate provoked more and more insights. Just as Sir Harold Jeffreys' opposition to continental drift was crucial in provoking a rigorous theory of plate tectonics, so Walker shows clearly how disputes about the snowball (for example, the contrary views of Nick Christie-Blick), brought deeper understanding.

Did Snowball Earth really happen? Sitting next to a scientific knight of excellent judgement at the end of Hoffman's peroration on receiving the Wegener Medal in 2001, I noted his warm applause (did he stamp his sandals? Was he clapping act or fact?), while I was still weighing the balance. Snowball Earth is entering the textbooks. Walker quotes a wildly improbable (but splendidly diverting) speculation that Hoffman will become a lord. In reality, like most scientists, geologists welcome but do not seek applause or rewards (or they'd have chosen easier and more remunerative jobs): their thrill is the chase. The details (snowball or slushball) remain hotly argued, and there are many false alarms and excursions, but there is an emerging consensus that something odd is being hunted down.

Is it important? The notion that Earth's climate has alternative stable states and can flip between them carries a warning for today. The stable climate of the past 10,000 years may be a freak — the hidden nightmare monsters that made the snowball may still be out there, especially methane. The Arctic sea floor and the continental shelves worldwide have widespread methane hydrates that will be released by warming. We are already turning Spitsbergen into fried ice-cream. Is it time to learn from geology's nightmares? Kyoto began the estrangement between the United States and Europe: maybe it could also begin the reconciliation. To get technical, either by a stand-alone methane agreement, or by resetting Kyoto's timescale for calculating global-warming potential from 100 years to a 'poor-nationfriendly' 20 years, and hence by placing more emphasis on vigorous cuts in methane emission, 